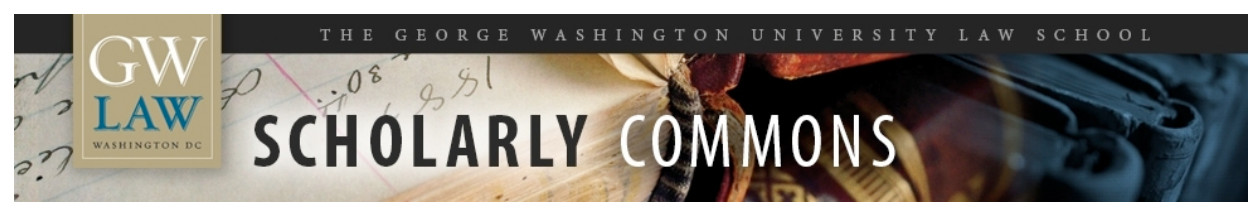

\title{
Linking Gender Security with the Armed Conflict to Peace Continuum
}

Naomi R. Cahn

George Washington University Law School, ncahn@law.gwu.edu

Fionnuala D. Ni Aolain

Dina Francesca Haynes

Follow this and additional works at: https://scholarship.law.gwu.edu/faculty_publications

Part of the Law Commons

\section{Recommended Citation}

Cahn, Naomi R.; Ni Aolain, Fionnuala D.; and Haynes, Dina Francesca, "Linking Gender Security with the Armed Conflict to Peace Continuum" (2011). GW Law Faculty Publications \& Other Works. 373.

https://scholarship.law.gwu.edu/faculty_publications/373

This Article is brought to you for free and open access by the Faculty Scholarship at Scholarly Commons. It has been accepted for inclusion in GW Law Faculty Publications \& Other Works by an authorized administrator of Scholarly Commons. For more information, please contact spagel@law.gwu.edu. 
Linking Gender Security with the Armed Conflict to Peace Continuum Abstract

Fionnuala Ní Aoláin, Dina Haynes and Naomi Cahn.

In the immediate aftermath of armed conflict, security is critical to the possibility that refugees, displaced persons, and former combatants will return home, that the rule of law can be established, and that the state can move forward positively. Security in a post-conflict society is critical to preventing further conflict. Available empirical evidence suggests that conflicts are highly cyclical and for societies experiencing internal conflict there is up to a $50 \%$ risk that conflict will again reignite. Security issues are at the heart of the reconstruction process for the local population, national leaders, and the international community. Security is also central to the psychological notion of safety and well-being at the individual and communal level. But what does "security" mean? We work from a layered conception of security, meaning security that encompasses both security from further state-supported armed groups and militia (typically conceived of as encompassing only public violence) and security to live in civil society without violence inflicted by post-conflict state actors in public societal settings as well as in the home. This essay examines the essential issue of security and its link to the establishment and maintenance of peace for women. It explores the multiple and contradictory versions of security that arise in societies transitioning away from violence. Our interest lies in ascertaining how women fare in these variable settings, and how concepts and implementation might be improved to make conflict transitions gender attentive. 
The analysis then unmasks the roles that gender and gendering play in security, showing how security priorities accord with masculine conceptualizations of safety, and critiquing the state-centric approach which focuses on public violence. Our micro analysis is focused primarily on security sector reform because that is the vehicle by which security in many post-conflict societies is conceptualized and delivered. We point to the weaknesses and limitations of existing frameworks and the ways in which gender bias is structured into existing solutions. Finally, we suggest a new paradigm for future efforts at security transitions that affects, and effects, equity between genders. We encourage a rethink of how conflict management processes manage and implement safety to the overall benefit of both men and women. 